\title{
Spatio-temporal Analysis of Land Cover Changes in Al-Hubail Wetland (Kingdom of Saudi Arabia)
}

Walid CHOUARI ( $\square$ walidchouari@yahoo.fr)

King Faisal University https://orcid.org/0000-0001-7038-8678

\section{Research Article}

Keywords: Land cover, classification, change detection, Al-Hubail wetland

Posted Date: November 12th, 2021

DOI: https://doi.org/10.21203/rs.3.rs-1034065/v1

License: (9) This work is licensed under a Creative Commons Attribution 4.0 International License. Read Full License 


\section{Abstract}

Land cover dynamics were analyzed temporally and spatially in Al-Hubail wetland (Al-Ahsa, Kingdom of Saudi Arabia) to determine the evolution of the environmental status of this biologically and ecologically interesting area in Saudi Arabia. Land cover changes were estimated for the next 41 years (1980-2021) using remote sensing data. For this analysis, three images from 1985 (Landsat 5 MSS) 2000 (Landsat 7 ETM+) and 2021 (Sentinel-2) were used to classify and detect changes. A machine learning algorithm was used and the images were classified into four main land cover classes: Water bodies, hydromorphic areas, vegetation and open ground. Change detection was performed for the year pairs 1985 to 2000 and 2000 to 2021. The results of this classification show that there was a significant increase in the area of hydromorphic areas and vegetation. The results were checked with a confusion matrix indicating an overall accuracy between 89.3 and $92.8 \%$. The qualitative trend data show that the Al-Hubail wetland has changed significantly during the study period. Thus, a significant expansion of the wetland was observed in conjunction with an increase in agricultural drainage towards the wetland. This analysis shows the strong anthropogenic pressure on the area and highlights the need to strengthen the existing laws in order to preserve the local biodiversity in the long term. It suggests that more efforts should be made to effectively manage the water resources of the region.

\section{Article Highlights}

- Assessment of the dynamics of land cover change in Al-Hubail wetland.

- Post-classification comparisons (PCCs) have been used to assess the change scenario of the wetland.

- The water body and vegetated land have increased significantly during the study period.

- The discharge of agricultural drainage water explains the dynamics of the study area.

\section{Introduction}

Despite their multiple functions and services to human society, wetlands are among the most threatened ecosystems worldwide by human activities: Pollution, use of biological resources, alteration of natural systems, impacts of agricultural activities, etc. (Gardner and Finlayson 2018; Van Asselen et al. 2013; Xu et al. 2019). The Al-Ahsa region in Saudi Arabia is characterized by a great diversity of wetland ecosystems and natural resources. This diversity is related to the large number of endemic species they host (Al-Dakheel et al. 2009; Al-Hussaini 2005; Al-Sheikh and Fathi 2010; Chouari 2021b; Eid et al. 2020; Fathi et al. 2009; Salih 2018; Youssef et al. 2009). However, the establishment of a drainage network in Al-Ahsa Oasis has led to increasing pressures on natural ecosystems and their biodiversity. These human pressures, depending on their intensity, lead to quantitative (degradation or fluctuation of the ecosystems' surface) and/or qualitative changes, resulting in dysfunction and loss of bioecological values of the natural environments (Abdel-Moneim 2014; Almadini et Hassaballa 2019; Al-Obaid et al. 2017; Chouari, 2021b). 
The aim of this paper is to analyze the land cover evolution in Al-Hubail wetland through a mapping method using multidata satellite imagery and a Geographic Information System (GIS). Remote sensing is a powerful tool for studying environmental issues (Al-Hussaini 2005; Almadini and Hassaballa 2019; Chouari 2021a, b; Maimaitijiang et al. 2015; Petropoulos et al. 2015; Rapinel et al. 2015). Satellite imagery provides valuable large-scale and multi-temporal data on land cover change. A number of change detection techniques have been developed to assess LULC changes using satellite data (Alwashe et al. 1993; Borak et al. 2000; Close 2021; Coppin et al. 2004; Lu et al. 2004; Rokni et al. 2015). Postclassification comparisons (PCCs) are commonly used (Coppin et al. 2004; Deng et al. 2008; Lu et al. 2004; Wu et al. 2017). Post-classification comparisons examine changes between independently classified land cover data over time. Three multispectral satellite images acquired at different times $(1985,2000$, and 2021) were used. The results are of great importance for decision making in wetland management and for predicting likely future development scenarios.

\section{Materials And Methods}

A change detection analysis was performed using thematic data derived from maximum likelihood classification of 1985 and 2000 Landsat imagery and 2021 Sentinel-2 imagery of the Al-Hubail wetland.

\section{Study area and data}

To offset water losses from the Al-Ahsa Oasis irrigation and drainage project in eastern Saudi Arabia, project management developed a strategy based on the use of non-traditional water sources such as treated wastewater and reuse of agricultural drainage water while reducing groundwater pumping from wells. Excess agricultural drainage water is discharged into two wetlands: Al-Asfar and Al-Hubail, which were originally two Sabkhas wetlands. Al-Hubail wetland is connected to the D1 canal of the Saudi Irrigation Organization (Fig. 1).

The wetland has a variety of natural environments (temporary pools, open ground, sand dunes, etc.), with ecosystems of great biological and ecological interest, which, thanks to the presence of water, allow the permanent and temporary settlement of exceptional flora (macrophytes, algae, riparian vegetation, etc.) and fauna (Tachybaptus ruficollis, Rallus aquaticus, Himantopus himantopus, Egretta garzetta Circus aeruginosus, Accipiter nisus etc.). The site is one of the first refuges for waterfowl in the Arabian Peninsula, but also one of their resting and feeding places. It attracts visitors, especially in winter, to enjoy the natural landscape and observe migratory birds. The birds migrate from cooler regions to areas with warmer climates, which include the Al-Hubail wetland. However, the water of the wetland is now contaminated with heavy metals, mainly from agricultural wastewater. The level of heavy metals is generally higher than the international permissible limits and fluctuates seasonally (Alfarhan 1999; AlTaher 1999; Ashraf et al. 2020; Fahmy et al. 2011; Salih 2018); (Fig. 2).

In order to assess the evolution of the Al-Hubail wetland, two Landsat images (MSS from 1985 and ETM+ from 2000) and one Sentinel-2 image (2021) were used for this analysis. All three images were acquired in the same season to avoid confusion in classification due to phonological changes. Because the area is 
often marshy and flooded in the wet season and dry in the summer, satellite imagery from the summer season (July and August) was primarily used to clearly extrapolate the different land covers. All data and information used in this study can be found in Table 1. The land cover maps resulting from the classifications of the satellite images were then used for the spatio-temporal comparison (Table 1). 
Table 1

All inputs for the classification of images in 1985, 2000 and 2021 (https://eos.com / https://www.usgs.gov/).

\begin{tabular}{|c|c|c|c|}
\hline Images & Bands and features & Wavelength $(\mu \mathrm{m})$ and description & $\begin{array}{l}\text { Resolution } \\
\text { (m) }\end{array}$ \\
\hline \multirow{8}{*}{$\begin{array}{l}\text { Landsat } 5 \\
\text { (MSS) } 1985\end{array}$} & band 1 - Visible Green & $0.5-0.6$ & 60 \\
\hline & band 2 - Visible Red & $0.6-0.7$ & 60 \\
\hline & band 3 - NIR & $0.7-0.8$ & 60 \\
\hline & band 4 - NIR & $0.8-1.1$ & 60 \\
\hline & \multirow{2}{*}{$\begin{array}{l}\text { NDVI (Normalized } \\
\text { Difference Vegetation } \\
\text { Index) }\end{array}$} & $(\mathrm{B} 4-\mathrm{B} 3) /(\mathrm{B} 4+\mathrm{B} 3)$ & \multirow[t]{2}{*}{60} \\
\hline & & $\begin{array}{l}\text { (Near-Infrared - Visible) / (Near-Infrared } \\
+ \text { Visible) }\end{array}$ & \\
\hline & \multirow{2}{*}{$\begin{array}{l}\text { NDWI (Normalized } \\
\text { Difference Water Index) }\end{array}$} & $(\mathrm{B} 4-\mathrm{B} 5)$ / (B4 + B5) & \multirow[t]{2}{*}{60} \\
\hline & & $\begin{array}{l}\text { Near-Infrared - Short-wave Infrared) / } \\
\text { (Near-Infrared + Short-wave Infrared }\end{array}$ & \\
\hline \multirow{12}{*}{$\begin{array}{l}\text { Landsat } 7 \\
(\text { ETM+) } \\
(2000)\end{array}$} & Band 1 - Visible & $0.45-0.52$ & 30 \\
\hline & Band 2 - Visible & $0.52-0.60$ & 30 \\
\hline & Band 3 - Visible & $0.63-0.69$ & 30 \\
\hline & Band 4 - Near-Infrared & $0.77-0.90$ & 30 \\
\hline & $\begin{array}{l}\text { Band } 5 \text { - Short-wave } \\
\text { Infrared }\end{array}$ & $1.55-1.75$ & 30 \\
\hline & Band 6 - Thermal & $10.40-12.50$ & $60(30)$ \\
\hline & Band 7 - Mid-Infrared & $2.09-2.35$ & 30 \\
\hline & Band 8 - Panchromatic & $0.52-0.90$ & 15 \\
\hline & \multirow{2}{*}{$\begin{array}{l}\text { NDVI (Normalized } \\
\text { Difference Vegetation } \\
\text { Index) }\end{array}$} & $(\mathrm{B} 4-\mathrm{B} 3) /(\mathrm{B} 4+\mathrm{B} 3)$ & \multirow[t]{2}{*}{30} \\
\hline & & $\begin{array}{l}\text { (Near-Infrared - Visible) / (Near-Infrared } \\
+ \text { Visible) }\end{array}$ & \\
\hline & \multirow{2}{*}{$\begin{array}{l}\text { NDWI (Normalized } \\
\text { Difference Water Index) }\end{array}$} & (B4 - B5) / (B4 + B5) & \multirow[t]{2}{*}{30} \\
\hline & & $\begin{array}{l}\text { (Near-Infrared - Short-wave Infrared) / } \\
\text { (Near-Infrared + Short-wave Infrared) }\end{array}$ & \\
\hline \multirow[t]{3}{*}{$\begin{array}{l}\text { Sentinel } 2 \\
(2021)\end{array}$} & $\begin{array}{l}\text { Band } 1 \text { - Ultra blue } \\
\text { (Coastal and Aerosol) }\end{array}$ & $0.421-0.457$ & 60 \\
\hline & Band 2 - Blue & $0.439-0.535$ & 10 \\
\hline & Band 3 - Green & $0.537-0.582$ & 10 \\
\hline
\end{tabular}




\begin{tabular}{|c|c|c|c|}
\hline Images & Bands and features & Wavelength $(\mu \mathrm{m})$ and description & $\begin{array}{l}\text { Resolution } \\
\text { (m) }\end{array}$ \\
\hline & Band 4 - Red & $0.646-0.714$ & 10 \\
\hline & $\begin{array}{l}\text { Band } 5 \text { - Visible and Near } \\
\text { Infrared (VNIR) }\end{array}$ & $0.694-0.714$ & 20 \\
\hline & $\begin{array}{l}\text { Band } 6 \text { - Visible and Near } \\
\text { Infrared (VNIR) }\end{array}$ & $0.731-0.749$ & 20 \\
\hline & $\begin{array}{l}\text { Band } 7 \text { - Visible and Near } \\
\text { Infrared (VNIR) }\end{array}$ & $0.768-0.796$ & 20 \\
\hline & $\begin{array}{l}\text { Band } 8 \text { - Visible and Near } \\
\text { Infrared (VNIR) }\end{array}$ & $0.767-0.808$ & 10 \\
\hline & $\begin{array}{l}\text { Band } 8 \text { A - Visible and } \\
\text { Near Infrared (VNIR) }\end{array}$ & $0.848-0.881$ & 20 \\
\hline & $\begin{array}{l}\text { Band } 9 \text { - Short Wave } \\
\text { Infrared (SWIR) }\end{array}$ & $0.931-0.958$ & 60 \\
\hline & $\begin{array}{l}\text { Band } 10 \text { - Short Wave } \\
\text { Infrared (SWIR) }\end{array}$ & $1.338-1.414$ & 60 \\
\hline & $\begin{array}{l}\text { Band } 11 \text { - Short Wave } \\
\text { Infrared (SWIR) }\end{array}$ & $1.539-1.681$ & 20 \\
\hline & $\begin{array}{l}\text { Band } 12 \text { - Short Wave } \\
\text { Infrared (SWIR) }\end{array}$ & 2.072-2.312 & 20 \\
\hline & \multirow{2}{*}{$\begin{array}{l}\text { NDVI (Normalized } \\
\text { Difference Vegetation } \\
\text { Index) }\end{array}$} & $(\mathrm{B} 8-\mathrm{B} 4) /(\mathrm{B} 8+\mathrm{B} 4)$ & \multirow[t]{2}{*}{10} \\
\hline & & (NIR - RED) / (NIR + RED) & \\
\hline & \multirow{2}{*}{$\begin{array}{l}\text { NDWI (Normalized } \\
\text { Difference Water Index) }\end{array}$} & $(\mathrm{B} 8-\mathrm{B} 12) /(\mathrm{B} 8+\mathrm{B} 12)$ & \\
\hline & & $(\mathrm{NIR}-\mathrm{MIR}) /(\mathrm{NIR}+\mathrm{MIR})$ & \\
\hline
\end{tabular}

\section{Classification of satellite images}

Pre-processing of the selected satellite images (radiometric and geometric corrections) was performed (Fontinovo et al. 2012; Nguyen 2015; Wang et al. 2012). This included radiometric calibrations to allow the transition from grayscale to apparent reflectance, the parameters of which were taken from the metadata of each image. After geometric correction of these images, the boundary of the study area was digitized to crop the satellite images and extract the area of interest. Moreover, all the field work was carried out with the help of instruments like Differential Global Positioning System (DGPS), topographic maps and digital camera. The exact location of each area representing each land cover has to be determined. These areas are called training areas. They were used to classify the satellite images and evaluate their accuracy (Table 2). 
Table 2

Data collected during training and testing for all images

\begin{tabular}{|c|c|c|c|c|c|c|c|c|}
\hline \multirow[b]{2}{*}{ Images' year } & \multicolumn{2}{|c|}{ Water bodies } & \multicolumn{2}{|c|}{ Vegetation } & \multicolumn{2}{|c|}{ Hydromorphic areas } & \multicolumn{2}{|c|}{ Open ground } \\
\hline & Train & Test & Train & Test & Train & Test & Train & Test \\
\hline 1985 & 40 & 80 & 45 & 91 & 53 & 88 & 40 & 115 \\
\hline 2000 & 52 & 89 & 57 & 110 & 61 & 120 & 49 & 120 \\
\hline 2021 & 38 & 68 & 53 & 115 & 72 & 120 & 40 & 92 \\
\hline
\end{tabular}

After preprocessing the images and deriving NDVI and NDWI features, the images are classified using maximum likelihood classification under Gaussian assumption to obtain land cover maps of the study area (Girard and Girard, 2010). The library of spectral signatures created in the training phase was fed into the maximum likelihood classifier to classify the satellite images. Thus, each pixel was classified according to its probability of belonging to a particular class. Field tests were conducted to evaluate the accuracy of the classification.

After selecting the channels to be subjected to the classification, training areas were selected by digitizing polygons of sufficiently large and homogeneous areas. Based on the knowledge of the terrain, the plots were located on each candidate image for classification. Their outlines were delineated avoiding the edge pixels to limit the variability within the plots. This was done to distinguish the following land uses on the satellite images: Water bodies, hydromorphic areas, vegetation, and open ground. The training plots were evaluated using a contingency matrix representing the confusion between the classes used for classification. This matrix was used to redefine these areas to avoid such confusion as much as possible.

\section{Evaluation of the detection of changes}

Change detection techniques assume that a change in surface coverage results in to a corresponding change in reflectance. Recently, many change detection techniques have been developed; the most commonly used are image differencing, principal component analysis, and post-classification comparisons (Close 2021; Deng et al. 2008; El-Hattab 2016; Lu et al. 2004; Ojaghi et al. 2017; Rokni et al. 2015; Wu et al. 2017). The detection method of post-classification comparisons (PCCs) is effective in determining the nature, rate, and location of change. PCC examines changes over time between independently classified land cover data (Almutairi and Warner 2010; El-Hattab 2016). The use of an independent classification procedure for each satellite image and low sensitivity to changes in acquisition conditions and features are some of the features of the PCC detection method.

The post-classification approach is the comparative analysis of classifications made independently for different data (El-Hattab 2015, 2016; Ojaghi et al. 2017). Thus, the method captures the classified satellite 
images using the maximum likelihood classification method. Moreover, the method provides information about the extent and distribution of the modified area according to each land cover, which is uniformly distributed among the multitemporal images. The pixel-to-pixel approach is also used to identify differences between objects or phenomena at different times (Deng 2008; Hussain et al. 2013; Nemmour and Chibani 2004; Rokni et al. 2015). This approach consists of simultaneous analysis of multispectral images.

Since the post-classification technique is directly dependent on the classification accuracy of the images, an assessment of classification accuracy was performed for each of the three images. In this study, a contingency matrix was used as a validation measure based on selected independent test patterns to evaluate the classification performance.

In the next step, a Geographic Information System-based overlay technique was applied to obtain the spatial changes in land cover over two time periods: $1985-2000$ and 2000-2021. The result of this technique is a cross matrix with two entries summarizing the main types of changes in the studied area. For each of the three four-class maps, a new thematic layer was created with different combinations of change classes.

\section{Spectral bands and features used for the classification}

Due to the presence of water and vegetation in the study area and in order to obtain a very accurate classification, the Normalized Difference Vegetation Index (NDVI) and the Normalized Difference Water Index (NDWI) were added outside the spectral band of the satellite imagery according to the following formulas as input to the classification algorithm (Fig. 3a-c and Fig. 4a-c).

$N D V I=X_{N I R}-X_{S W I R} / X_{N I R}+X_{S W I R}$

$\mathrm{NDWI}=\mathrm{X}_{\mathrm{Green}}-\mathrm{X}_{\mathrm{NIR}} / \mathrm{X}_{\mathrm{Green}}+\mathrm{X}_{\mathrm{NIR}}$

Figures 3a-c and 4a-c show the NDVI and NDWI derived for each of the satellite images. These extracted indices in combination with the spectral bands of the satellite images allow the classification of each image. Table 1 provides information on all spectral bands and indices that contributed to the classification of the 1985, 2000, and 2021 images.

\section{Results And Discussion}

After the creation of the classification maps, a post-classification change detection changes was performed. The results of this classification were compared with the accuracy of the land cover maps and topographic maps. In this section, the results of land cover classification and change detection are presented.

\section{Land cover maps}


Change detection is based on satellite image classification. The process of image classification and creation of thematic land cover maps consists mainly of three steps: the extraction of training data, the creation and training of the classifier model, and finally the evaluation of the accuracy of the created maps using the test data. In the first and third stages of this process, the number and method of collecting training and testing data play an important role in the quality of classification and change detection. For this reason, in this work, the collection of training and testing data was not only done by field surveys, but DGPS and satellite imagery were also used in this step to collect very reliable data. Table 2 shows the number of training and test data extracted to train the classifier and evaluate the accuracy of the maps produced in 1985, 2000 and 2021 (Fig. 5a-c).

The derived land cover maps for 1985, 2000 and 2021 are shown in Figures 5a-c. The extent of hydromorphic area and vegetation classes can be visually seen on these maps. Table 3 shows the confusion matrix for the classification maps (Table 3).

Table 3

Average contingency matrix for the three satellite images of 1985, 2000 and 2021 (in \%).

\begin{tabular}{|lllll|}
\hline Classes & Water bodies & Hydromorphic areas & Vegetation & Open ground \\
\hline Water bodies & $\mathbf{9 2 . 6}$ & 4.8 & 2.3 & 2.1 \\
\hline Hydromorphic areas & 4.1 & $\mathbf{8 8 . 4}$ & 3.2 & 4.2 \\
\hline Vegetation & 2.5 & 3.9 & 93.3 & 2.9 \\
\hline Open ground & 0.8 & 2.9 & 1.2 & 90.8 \\
\hline
\end{tabular}

Roughly speaking, four land cover classes each have a distinct spectral behavior in all the satellite images used: Water bodies, vegetation, hydromorphic areas and open ground. Also, the comparison between the three contingency matrices created for the years 1985, 2000 and 2021 shows a constant improvement in the separability of the land cover classes. The overall classification accuracy for the 1985,2000 , and 2021 scene classification was $89.3 \%, 91.4 \%$, and $92.8 \%$, respectively, which was considered acceptable for accuracy evaluation. Thus, the accuracy of the land cover map of the most recent date (2021) improved compared to that of an older date (1985). Thus, the average accuracy resulting from the combination of the four confusion matrices developed for the three land cover maps is $90.2 \%$.

\section{Change detection results}

To determine the extent of land cover change in the Al-Hubail wetland, a Geographic Information System (GIS) was overlaid to detect the changes between 1985 and 2000 in Fig. 6a and between 2000 and 2021 in Fig. $6 \mathrm{~b}$. The change maps are shown in Fig. 6a-b and show significant changes in the land cover of the study area. 
Table 4 shows the area occupied by each land cover class. Analysis of this table shows a significant increase in hydromorphic areas and vegetated areas over the last four decades. Hydromorphic areas have increased from $7.91 \mathrm{~km}^{2}(2.69 \%)$ to $7.62 \mathrm{~km}^{2}$ (2.59\%) from 1985 to 2000 and to $20.05 \mathrm{~km}^{2}(6.82 \%)$ by 2021 .

Table 4

Area coverage of land cover classes for the study area from 1985 to 2021.

\begin{tabular}{|lllllll|}
\hline Classes & 1985 & \multicolumn{3}{c}{2000} & \multicolumn{3}{c|}{2021} \\
\cline { 2 - 7 } & $\mathrm{Km}^{2}$ & $\%$ & $\mathrm{Km}^{2}$ & $\%$ & $\mathrm{Km}^{2}$ & $\%$ \\
\hline Water bodies & 4.12 & 1.4 & 7.85 & 2.67 & 3.71 & 1.26 \\
\hline Hydromorphic areas & 7.91 & 2.69 & 7.62 & 2.59 & 20.05 & 6.82 \\
\hline Vegetation & 1.62 & 0.55 & 2.43 & 1.21 & 6.82 & 2.32 \\
Open ground & 280.18 & 95.32 & 276.03 & 93.53 & 263.35 & 89.59 \\
\hline Total & 293.93 & 100 & 293.93 & 100 & 293.93 & 100 \\
\hline
\end{tabular}

Figure 7 shows the percent change in each land cover between 1985 and 2021. Figure 7 shows different trends for each land cover. Wetlands comprised about $1.4 \%$ of the study area in 1985, and then increased sharply to over $6.8 \%$ in 2021 . Despite the ongoing conflict between water and sand in the area, the area of wetlands (aquatic and hydromorphic) gradually increases from about $4 \%$ in 1985 to $5.2 \%$ in 2000 and then rapidly increases to nearly $12 \%$ in 2021 . The vegetated area also increases gradually from $0.38-$ $2.32 \%$ between 1985 and 2021. Overall, there is a strong trend of increasing water and vegetated areas between 1985 and 2021, while at the same time there is a strong decrease in open ground area, which is related to an increasing input of drainage water into the Al-Hubail depression (Fig. 7).

Tables 5 and 6 show the result of the contingency table. They summarize the main changes land cover during the periods $1985-2000$ and 2000-2021.

Table 5

Details of the change in wetland area between 1985 and 2000 in $\mathrm{km}^{2}$.

\begin{tabular}{|llllll|}
\hline \multirow{2}{*}{ Classes } & \multicolumn{1}{l}{1985} & & & \\
\cline { 3 - 6 } & Water bodies & Hydromorphic areas & Vegetation & Open ground \\
\cline { 2 - 6 } & Water bodies & 2.53 & 0.69 & 0.22 & 4.41 \\
\cline { 2 - 5 } & Hydromorphic areas & 0.31 & 3.84 & 1.15 & 2.32 \\
\hline Vegetation & 0.35 & 0.91 & 0 & 1.67 \\
\hline Open ground & 0.93 & 2.47 & 0.25 & 280.18 \\
\hline
\end{tabular}


As shown in Table 5, most hydromorphic areas increased in size (about $2.32 \mathrm{~km}^{2}$ and $9.89 \mathrm{~km}^{2}$, respectively) due to conversion of areas that were previously open ground.

Table 6

Details of change in wetland area between 2000 and 2021 in km².

\begin{tabular}{|clllll|}
\hline \multirow{2}{*}{ Classes } & \multicolumn{2}{l}{2000} & & & \\
\cline { 3 - 6 } & & Water bodies & Hydromorphic areas & Vegetation & Open ground \\
\cline { 2 - 6 } & Water bodies & 2.48 & 0.37 & 0.65 & 0.21 \\
\cline { 2 - 5 } & Hydromorphic areas & 3.46 & 3.91 & 2.79 & 9.89 \\
\hline Vegetation & 0.82 & 1.07 & 0 & 6.05 \\
\hline Open ground & 1.09 & 2.27 & 0.11 & 258.76 \\
\hline
\end{tabular}

A huge transformation between vegetation and hydromorphic areas $\left(1.07 \mathrm{~km}^{2}\right)$ also occured between 2000 and 2021. As shown in Table 6, the conversion of approximately $6.05 \mathrm{~km}^{2}$ of open ground resulted in vegetated area.

\section{Conclusion}

The aim of this study was to record and analyze the land cover changes in Al-Hubail wetland in northeastern Al-Ahsa, eastern Saudi Arabia. The study area has changed dramatically during the last two decades due to various reasons, such as the discharge of increasing amounts of irrigation water into the wetland. To achieve this objective, multispectral and temporal satellite images (Landsat 5 MSS, Landsat 7 ETM+ and Sentinel 2) from 1985, 2000 and 2021 were used. After pre-processing the satellite images and in order to achieve a highly accurate classification, the water and vegetation indices (NDVI and NDWI) were integrated with the spectral bands of the satellites and used as input for the classification process. To classify the images and generate land cover maps for different selected years, a supervised maximum likelihood classification algorithm is used. Based on the obtained land cover maps, postclassification comparisons (PPCs) change detection methods are used to analyze the land cover between 1985-2000 and 2000-2021. In general, the results showed a remarkable change within the Al-Hubail wetland and its surroundings between 1985 and 2021. The most significant change was found in the hydromorphic area class, which increased from $2.32 \mathrm{~km}^{2}$ in 1985 to $9.89 \mathrm{~km}^{2}$ in 2021 at the expense of the open ground class. This study expresses that remote sensing and GIS are important technologies for temporal analysis of environmental phenomena that would otherwise not be possible with obsolete techniques. With these technologies, it is now possible to detect changes more accurately, more quickly, and at a lower cost. 


\section{Declarations}

\section{Acknowledgments}

The author acknowledges the Deanship of Scientific Research at the King Faisal University for the financial support under Nasher Track (Grant No. .......).

\section{References}

1. Abdel-Moneim A (2014) Histopathological and ultrastructural perturbations in tilapia liver as potential indicators of pollution in Lake AlAsfar, Saudi Arabia. Environ Sci Pollut Res 21:4387-439. https://doi.org/10.1007/s11356-013-2185-9

2. Al-Dakheel YY, Hussein AHA, El-Mahmoudi AS, Massoud MA (2009) Soil, water chemistry and sedimentological studies of Al Asfar evaporation lake and its Inland sabkha, Al-Hassa area, Saudi Arabia. Asian J Earth Sci 2:1-21. DOI: 10.3923/ajes.2009.1.21

3. Alfarhan AH (1999) A phytogeographical analysis of the floristic elements in Saudi Arabia. Pak. J. Biol. Sci., 2: 702-711. DOI: 10.3923/pjbs.1999.702.711

4. Al-Hussaini YA (2005) The use of multi-temporal Landsat TM imagery to detect land cover/use changes in AlHassa, Saudi Arabia. Scientific Journal of King Faisal University (Basic and Applied Sciences) 6 (1): 1426.

5. Almadini AM, Hassaballa AA (2019) Depicting changes in land surface cover at AlHassa oasis of Saudi Arabia using remote sensing and GIS techniques. PLoS ONE 14 (11): e0221115. https://doi.org/10.1371/journal.pone.0221115

6. Almutairi A, Warner TA (2010) Change detection accuracy and image properties: a study using simulated data. Remote Sens 2:1508-1529. https://doi.org/10.3390/rs2061508

7. Al-Obaid S, Samraoui B, Thomas J, El-Serehy HA, Alfarhan AH, Schneider W, O'Connell M (2017) An overview of wetlands of Saudi Arabia: Values, threats, and perspectives. Ambio 46:98- 108. https://doi.org/10.1007/s13280-016-0807-4

8. Al-Sheikh H, Fathi AA (2010) Ecological studies on Al-Asfar Lake. Al-Hassa, Saudi Arabia, with special references to the sediment. Res J Environ Sci 4:13-22. https://doi: 10.3923/rjes.2010.13.22

9. Al-Taher AA (1999) Al-Hassa: Geographical Studies. King Saud University, College of Arts, Riyadh, pp: 1-385

10. Alwashe MA, Bokhari AY (1993) Monitoring vegetation changes in Al Madinah, Saudi Arabia, using Thematic Mapper data. International Journal of Remote Sensing, 14: 191-197. https://doi.org/10.1080/01431169308904331

11. Ashraf MY, Al-Fredan MA, Fathi AA (2020) Floristic Composition of Lake Al-Asfar, Alahsa, Saudi Arabia. International Journal of Botany, 5: 116-125. https://scialert.net/fulltext/? doi=ijb.2009.116.125 
12. Borak JS, Lambin EF, Strahler AH (2000) The use of temporal metrics for land-cover change detection at coarse spatial scales. International Journal of Remote Sensing, 21: 6-7, 1415-1432. https://doi: 10.1080/014311600210245

13. Chouari W (2021a) Contributions of multispectral images to the study of land cover in wet depressions of eastern Tunisia, The Egyptian Journal of Remote Sensing and Space Sciences, 24, 443-451. https://doi.org/10.1016/j.ejrs.2020.11.003.

14. Chouari W (2021b) Wetland land cover change detection using multitemporal Landsat data: a case study of the Al-Asfar wetland, Kingdom of Saudi Arabia. Arab J Geosci 14, 523. https://doi.org/10.1007/s12517-021-06815-y

15. Close O, Petit S, Beaumont B, Hallot E (2021) Evaluating the Potentiality of Sentinel-2 for Change Detection Analysis Associated to LULUCF in Wallonia, Belgium. Land, 10, 55. https://doi.org/10.3390/land 10010055

16. Coppin P, Jonckheere I, Nackaerts K, Muys B, Lambin E (2004) Review ArticleDigital change detection methods in ecosystem monitoring: a review. Int J Remote Sens 25:15651596. https://doi.org/10.1080/0143116031000101675

17. Deng JS, Wang K, Deng YH, Qi GJ (2008) PCA-based land-use change detection and analysis using multitemporal and multisensor satellite data. Int. J. Remote. Sens. 29, 4823-4838. https:// doi:10.1080/01431160801950162

18. Eid A, Olatubara CO, Ewemoje TA, Farouk H, El-Hennawy MT (2020) Coastal wetland vegetation features and digital change detection mapping based on remotely sensed imagery: El-Burullus Lake, Egypt. Int Soil Water Conserv Res 8:66-79. https://doi.org/10.1016/j.iswcr.2020.01.004

19. El-Hattab MM (2016) Applying post classification change detection technique to monitor an Egyptian coastal zone (Abu Qir Bay). Egyptian J Remote Sensing Space Sci 19:23-36. https://doi:10.1016/j.ejrs.2016.02.002

20. El-Hattab M.M., (2015) Change detection and restoration alternatives for the Egyptian lake maryut, Egypt. J. Remote Sens. Space Sci., 18, pp. 9-16; https://doi.org/10.1016/j.ejrs.2014.12.001

21. Fahmy GH, Fathi AA (2011) Limnological Studies on the Wetland Lake, Al-Asfar, with Special References to Heavy Metal Accumulation by Fish. American Journal of Environmental Sciences, 7(6), 515-524. https://doi.org/10.3844/ajessp. 515-524

22. Fathi AA, Al-Fredan MA, Youssef AM (2009) Water quality and phytoplankton communities in Lake Al-Asfar, AL-Hassa, Saudi Arabia. Res J Environ Sci 3:504-513. DOI:10.3923/rjes.2009.504.513

23. Fontinovo G, Allegrini A, Atturo C, Salvatori R (2012) Speedy methodology for geometric correction of MIVIS data. Eur J Remote Sens 45:19-25. https://doi.org/10.5721/EuJRS20124502

24. Gardner R, Finlayson M (2018) Global Wetland Outlook: State of the World's Wetlands and Their Services to People; Ramsar Convention: Gland, Switzerland.

25. Girard MC, Girard CM (2010) Traitement des données de télédétection-2e éd. : Environnement et ressources naturelles. Dunod, Paris. $576 \mathrm{p}$. 
26. Hussain M, Chen D, Cheng A, Wei H, Stanley D (2013) Change detection from remotely sensed images: From pixel-based to object-based approaches. ISPRS J. Photogramm. Remote. Sens. 80, 91106. https://doi.org/10.1016/j.isprsjprs.2013.03.006

27. Lu D, Mausel P, Brondízio E, Moran E (2004) Change detection techniques. Int. J. Remote. Sens. 25, 2365-2401. https://doi.org/10.1080/0143116031000139863

28. Maimaitijiang M, Ghulam A, Sandoval JO, Maimaitiyiming M (2015) Drivers of land cover and land use changes in St. Louismetropolitan area over the past 40 years characterized by remote sensing and census population data. Int J Appl Earth Obs Geoinf 35:161-174.

DOI:10.1016/j.jag.2014.08.020

29. Nemmour H, Chibani Y (2006) Multiple support vector machines for land cover change detection: An application for mapping urban extensions, ISPRS Journal of Photogrammetry and Remote Sensing, 61, 2, 125-133. DOI:10.1007/s12524-011-0060-z

30. Nguyen TH (2015) Optimal ground control points for geometric correction using genetic algorithm with global accuracy. Eur J Remote Sens 48(1):101-120. https://doi.org/10.5721/EuJRS20154807

31. Ojaghi S, Ahmadi FF, Ebadi H, Bainchetti R (2017) Wetland cover change detection using multitemporal remotely sensed data. A case study: Ghara Gheshlagh wetland in the southern part of the Urmia Lake. Arab J Geosci 10:470. https://doi.org/10.1007/s12517-017-3239-y

32. Petropoulos GP, Dionissios P. Kalivas DP, Griffiths HM, Paraskevi P, Dimou PP (2015) Remote sensing and GIS analysis for mapping spatio-temporal changes of erosion and deposition of two Mediterranean river deltas: The case of the Axios and Aliakmonas rivers, Greece, International Journal of Applied Earth Observation and Geoinformation, Volume 35, Part B, 217-228. https://doi.org/10.1016/j.jag.2014.08.004

33. Rapinel S, Hubert-Moy L, Clément B (2015) Combined use of LiDAR data and multispectral earth observation imagery for wetland habitat mapping, International Journal of Applied Earth Observation and Geoinformation 37, 56-64. https://doi.org/10.1016/j.jag.2014.09.002

34. Rokni K, Ahmad A, Solaimani K, Hazini S (2015) A new approach for surface water change detection: integration of pixel level image fusion and image classification techniques. Int. J. Appl. Earth Obs. Geoinf., 34, 226-234. https://doi.org/10.1016/j.jag.2014.08.014

35. Salih A (2018) Classification and mapping of land cover types and attributes in Al-Ahsaa Oasis, Eastern Region, Saudi Arabia Using Landsat-7 Data. J. Remote Sensing \& GIS. 7: 228. https://doi.org/ 10.4172/2469-4134.1000228

36. Asselen Sv, Verburg PH, Vermaat JE, Janse JH (2013) Drivers of Wetland Conversion: a Global MetaAnalysis. PLoS ONE 8(11): e81292. https://doi.org/10.1371/journal.pone.0081292

37. Wang J, Yong Gea Y, Heuvelinkc G, Zhoua C, Brusd D (2012) Effect of the sampling design of ground control points on the geometric. Arab J Geosci (2021) 14:523 Page 13 of 14523 correction of remotely sensed imagery. Int J Appl Earth Obs Geoinf 18:91-100. DOI:10.1016/j.jag.2012.01.001

38. Wu C, Du B, Cui X, Zhang L (2017) A post-classification change detection method based on iterative slow feature analysis and Bayesian soft fusion. Remote. Sens. Environ. 199, 241-255. 
https://doi.org/10.1016/j.rse.2017.07.009

39. Xu T, Weng B, Yan D, Wang K, Li X, Bi W, Li M, Cheng X, Liu Y (2019) Wetlands of International Importance: Status, Threats, and Future Protection, Int. J. Environ. Res. Public Health, 16, 1818. DOI:10.3390/ijerph16101818

40. Youssef AM, Al-Fredan MA, Adel A, Fathi AA (2009) Floristic composition of Lake Al-Asfar, Alahsa, Saudi Arabia. Int J Bot 5:116-125. https://doi.org/10.3923/ijb.2009.116.125

\section{Figures}
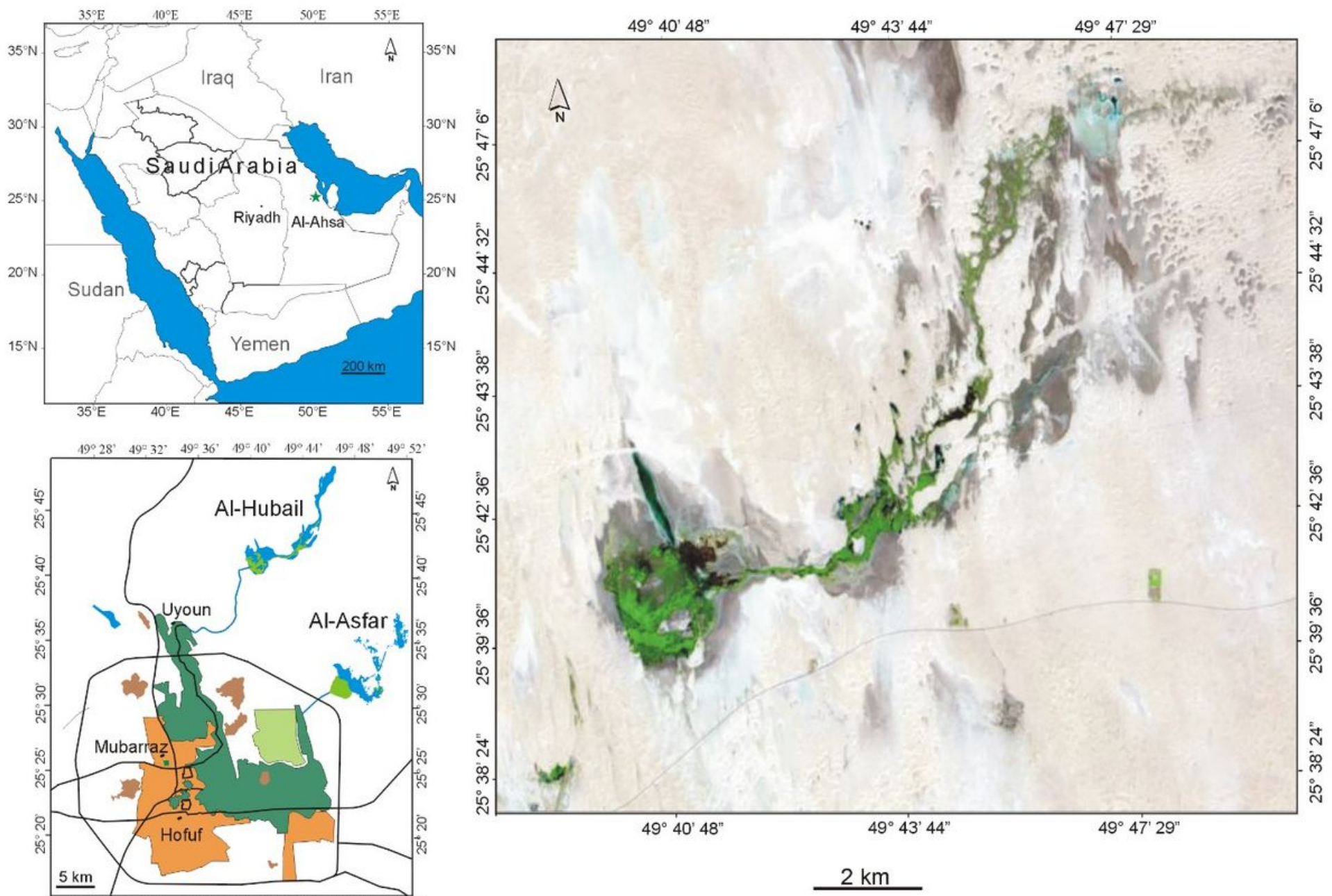

\section{Figure 1}

Geographical location of the Al-Hubail wetland (eastern Saudi Arabia). 


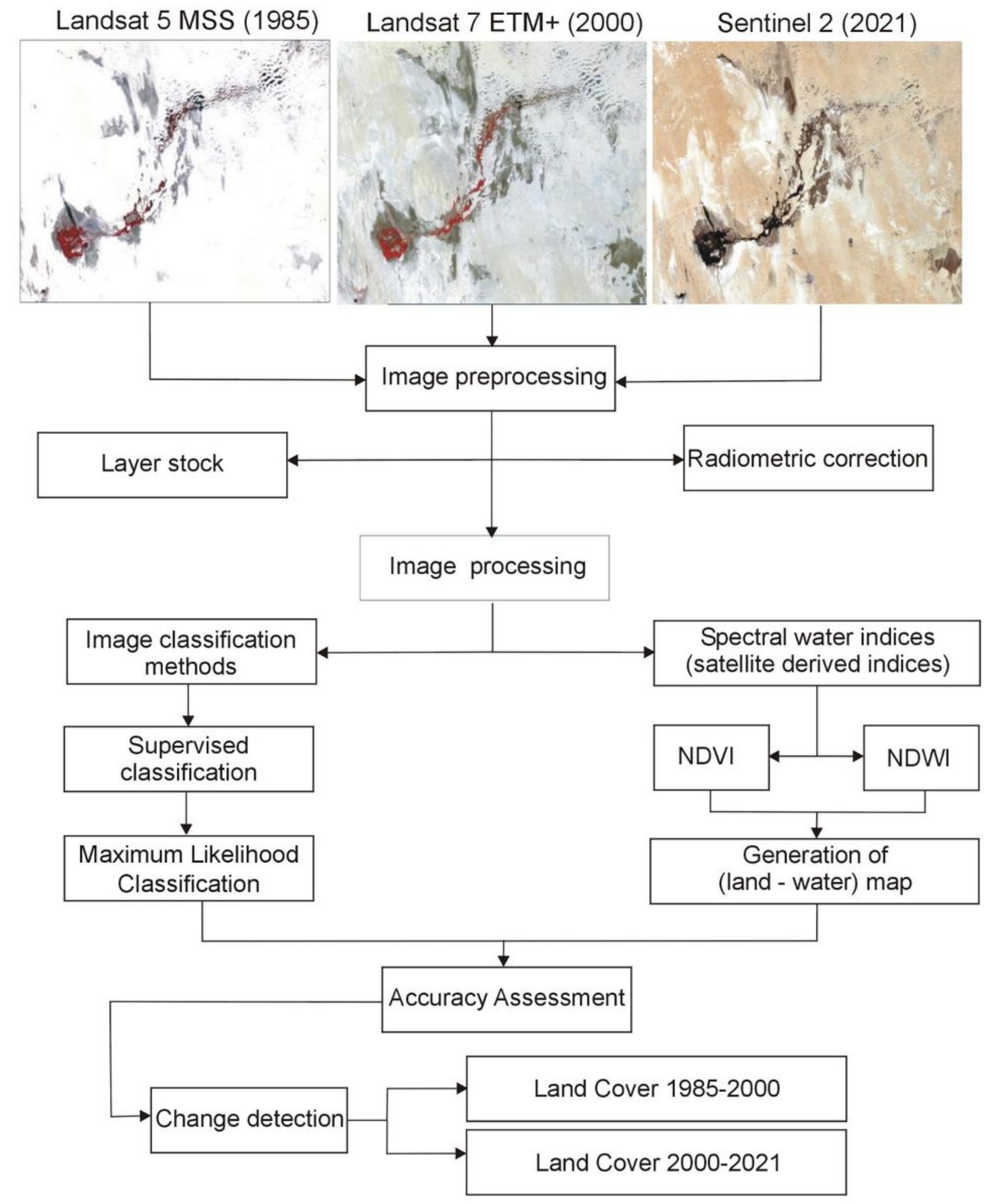

Figure 2

The flow chart of the applied methodology 


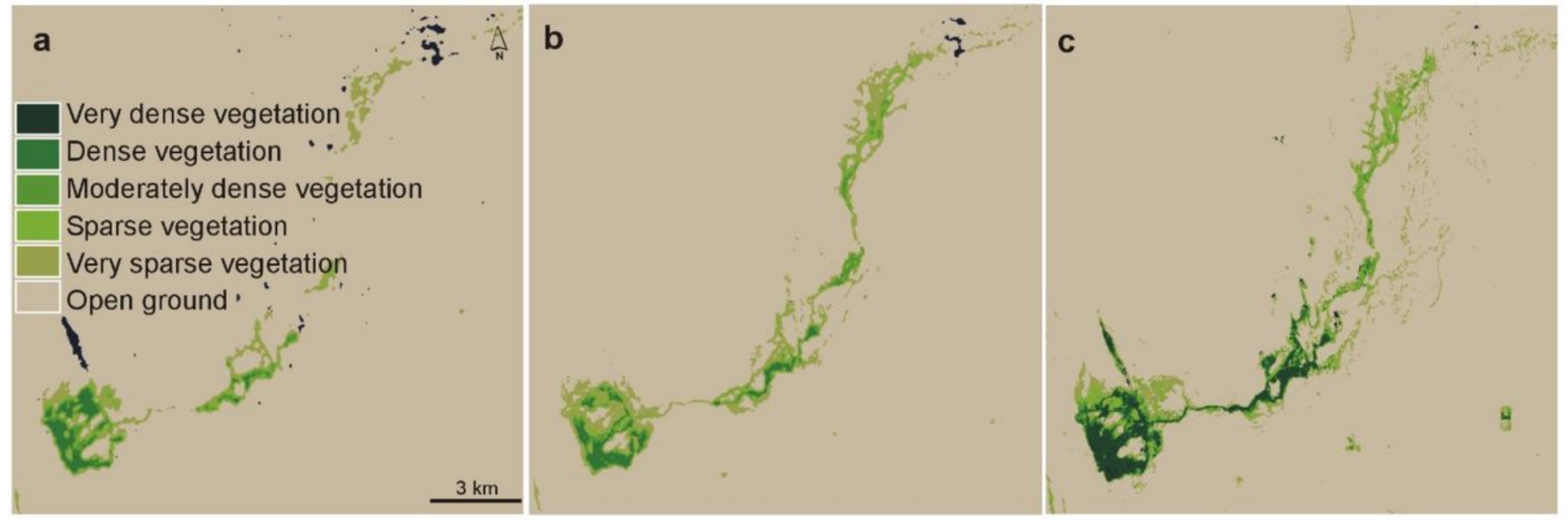

\section{Figure 3}

$a-c$ NDVI

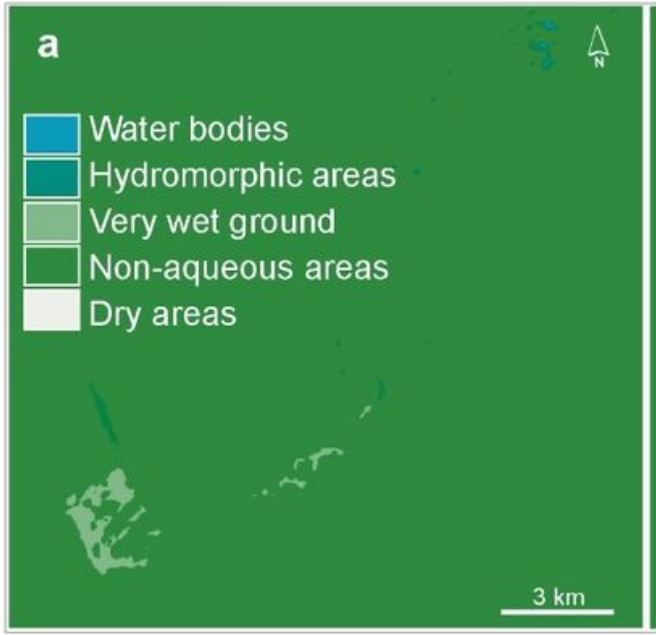

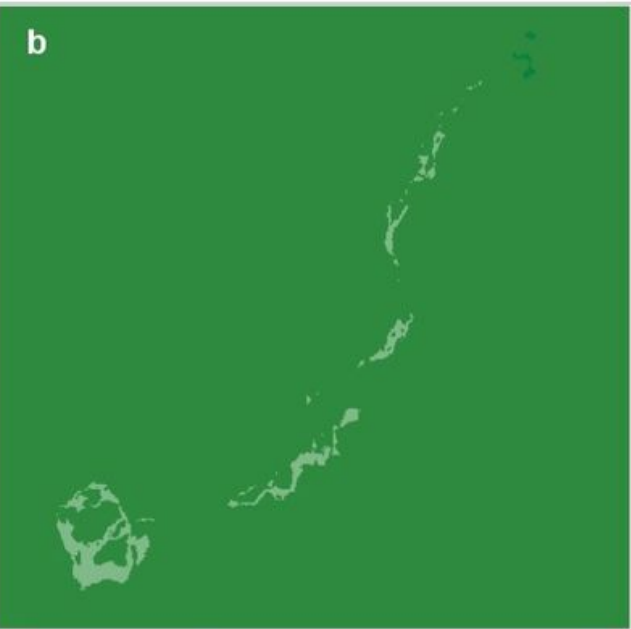

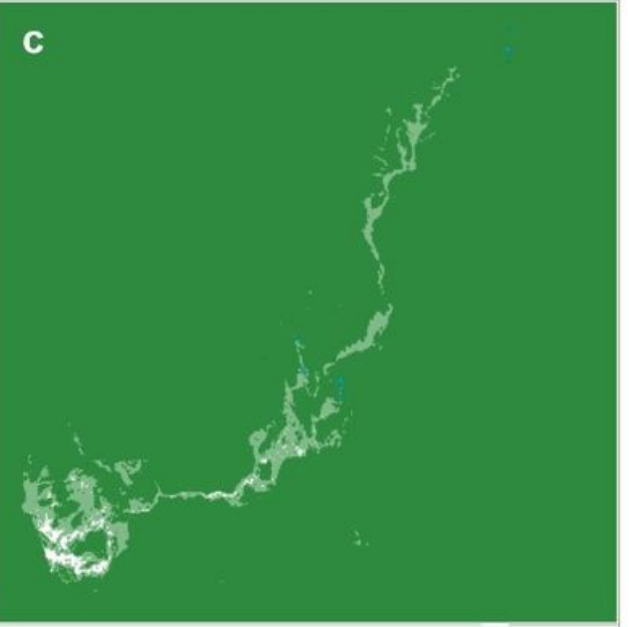

\section{Figure 4}

$a-c N D W I$

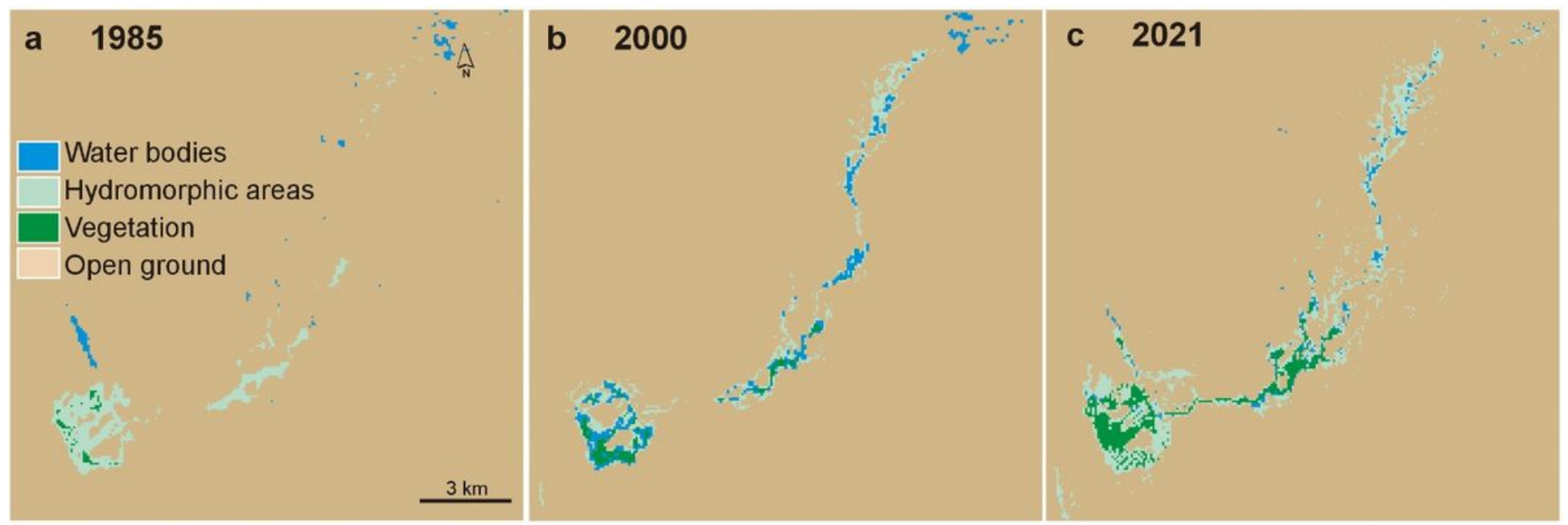

\section{Figure 5}



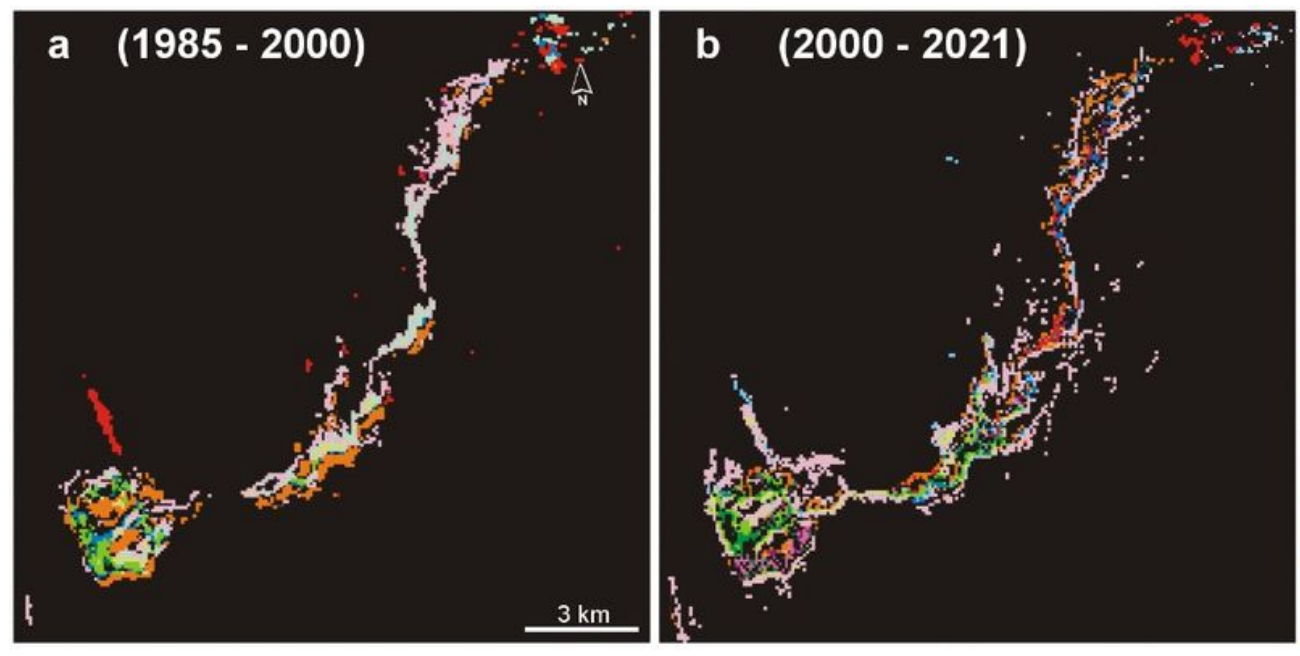

No change

Hydromorphic area to water body Vegetation to water body Open ground to water body Water body to vegetation Hydromorphic area to vegetation Open ground to vegetation Water body to hydromorphic area Vegetation to hydromorphic area Open ground to hydromorphic area Water body to open ground Hydromorphic area to open ground Vegetation to open ground

\section{Figure 6}

$a-b$ Change detection maps

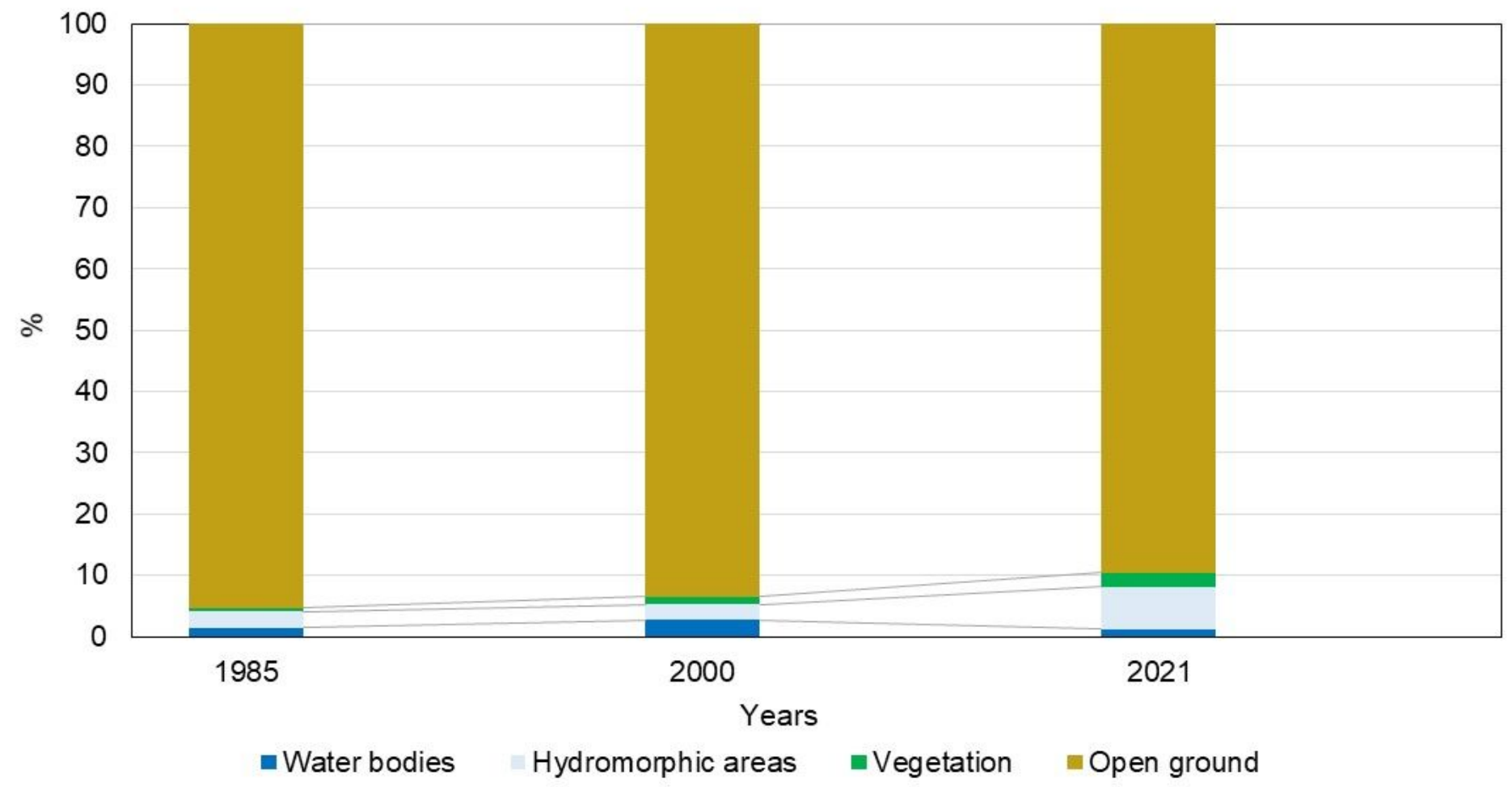

Figure 7

Evolution of land cover in the Al-Hubail wetland (1985-2021).

\section{Supplementary Files}

This is a list of supplementary files associated with this preprint. Click to download. 
- GraphicalAbstract.docx

Page 19/19 